Reprod. Nutr. Dévelop., 1983, 23 (2 A), 285-292.

\title{
Thecal vasculature and oocyte maturation during follicular atresia in the sheep and pig
}

\author{
D. G. CRAN, J. C. OSBORN, Deborah RUSHTON
}

Agricultural Research Council, Institute of Animal Physiology, Animal Research Station, 307 Huntingdon Road, Cambridge CB3 OJQ, U.K.

Summary. During follicular atresia in the sheep and pig there is a marked reduction in the vasculature of the theca interna underlying the membrana granulosa. In the sheep there is no reduction of thecal blood vessels adjacent to the cumulus which remains viable. By contrast, in the pig the cumulus degenerates during atresia and the underlying thecal vasculature is greatly diminished. However, despite loss of contact between the follicle cells and the oocyte, the germinal vesicle remains intact.

\section{Introduction.}

In most species studied, atresia results in the degeneration of both the granulosa and cumulus cells (Weir and Rowlands, 1977; Byskov, 1978). In the sheep (Hay and Cran, 1978) and cow (Rajakoski, 1960), however, although the granulosa undergoes similar degenerative changes to those seen in other species, they are not evident within the cumulus until a late stage of atresia. The presence of both healthy and degenerative areas within the same follicle would suggest that a local factor is exerting a protective influence. One of the factors implicated with follicular atresia is a diminution of the thecal vasculature resulting in a limitation of substrates available to the granulosa (Greenwald, 1974; Hay, Cran and Moor, 1976) or to a decrease in elimination of metabolic by products. Using morphological criteria, we have examined the thecal vasculature under both the cumulus and granulosa of sheep follicles and, for comparative purposes, have examined another domestic species, the pig.

Ultrastructural and histochemical changes in the oocyte have been considered as early signs of follicular regression (Byskov, 1978) and these may be followed by the formation of a pseudomaturation spindle and abnormal cleavage. However, it has recently been reported for the rat that degeneration of the cumulus and granulosa cells precedes that of the oocyte (Peluso, 1979; Gondos, 1982). In tertiary atretic sheep follicles neither degeneration of cumulus cells nor 
oocyte pseudo-maturation occur (Hay, Cran and Moor, 1976). We have, therefore, examined the relationship, in atretic pig follicles, of the meiotic status of the oocyte to the integrity of the cumulus both in vivo and in vitro.

\section{Materials and methods.}

Examination of vasculature. - Follicles $(2.0-6.0 \mathrm{~mm}$ diameter) were dissected from ovaries of sheep and pigs slaughtered at a local abattoir. Sheep follicles were macroscopically graded according to their degree of translucency and gross vascularity (Moor et al., 1978) into those which were non-atretic $(n=35)$ or in tertiary atresia $(n=35$ ) (Hay, Cran and Moor, 1976). Two similar groups of pig follicles were made $(n=6)$ based on microscopical assessment.

That part of the follicle wall bearing the cumulus, and wall diametrically opposite were processed for electron microscopy (Hay, Cran and Moor, 1976). One micron thick sections were cut of the two regions and stained with $1 \%$ toluidine blue in $1 \%$ borax. Photographs were taken of all blood vessels in the sections using $\times 63$ oil immersion objective and prints at a final magnification of $\times 1134$ made. Tracings were made of the blood vessels, cut out, weighed, and their areas calculated from a standard. The mean capillary size was calculated for the two areas in each follicle and the total mean for all nonatretic or atretic follicles calculated.

Examination of oocyte nuclei. - Ten pig ovaries were fixed in Bouin's solution, serial sections cut at $8 \mu \mathrm{m}$ and stained with haematoxylin and chromotrope. Forty oocytes within sectioned atretic follicles were examined.

A further 172 follicles were dissected from pig ovaries and 82 cultured for $48 \mathrm{~h}$ using techniques described previously (Moor and Trounson, 1977). Only follicles with a diameter $>6 \mathrm{~mm}$ were used since it was considered that the choice of a narrow size range would both aid identification of atresia and ensure a uniform population. Immediately after dissection the follicles were classified into three grades on the basis of macroscopical criteria. Grade 1 were classed as nonatretic. These had a rosy appearance with a prominent vasculature. Very few pyknotic nuclei were present in such follicles. Grade 2, classified as intermediate, had an orange colouration and lacked prominent blood vessels. Sections showed a reduced capillary bed as compared with Grade 1 and the presence of pyknotic nuclei in both the granulosa and theca interna. Grade 3, classed as atretic, were grey and clearly showed clumps of granulosa which had sloughed off into the antrum. Sections revealed the presence of numerous dead cells and confirmed the general loss of the granulosa.

After the $48 \mathrm{~h}$ culture period the follicles were opened, the oocytes denuded using graded pipettes and the nuclei examined in whole mounts. A further 90 follicles were opened after dissection from the ovaries and the oocytes removed. Of these, 15 were cultured for $48 \mathrm{~h}$ and the remainder examined immediately for their nuclear status. 
Results.

In the sheep, structural changes in atretic follicles including the disorganization of the granulosa and nuclear pyknosis were observed as has been previously reported (Hay, Cran and Moor, 1976 ; O'Shea, Hay and Cran, 1978). In such follicles, the cumulus showed no signs of degeneration. In addition, ultrastructural examination of the theca interna under the cumulus indicated that it had a structure essentially identical to that of non-atretic follicles (O'Shea et al., 1978).

Within non-atretic follicles, the mean capillary size under the cumulus and within the remainder of the wall were similar (table 1). In contrast, that under the cumulus of atretic follicles was significantly greater than in the remainder of the wall $(t=3.45 ; p<0.001)$ and was similar to that associated with the cumulus and wall of non-atretic follicles.

In the pig, prominent blood vessels were present within the theca interna underlying both the granulosa and cumulus (fig. 1). Atresia was characterised by the presence of numerous pyknotic nuclei within the granulosa (fig. 2). Such nuclei were not common within the theca interna, but this underwent a marked "loosening " of its structure with individual cells being more widely separated than in non-atretic follicles (fig. 2). With regard to the granulosa, the stages of atresia examined in the pig appeared to be comparable with secondary and tertiary atresia in the sheep. In the pig, the cumulus of atretic follicles underwent degenerative changes similar to those observed in the wall (fig. 3) although those cells abutting onto the oocyte remained viable longer than the remainder of the cumulus. There was a marked reduction in thecal capillary size both under the cumulus and granulosa as compared with non-atretic follicles (table 1). In the pig, the mean capillary area beneath the granulosa was reduced by some $75 \%$ while, in a similar area in the sheep, the reduction was in the order of some $40 \%$.

Examination of oocytes from atretic pig follicles, ( $n=92$ ) both in sections and as whole mounts, demonstrated that all but one contained an intact germinal vesicle (GV) (figs. 3 and 4) (table 2) and, as far as can be judged from their ultrastructural appearance, had not undergone any marked structural change during the stages of atresia examined (figs. 5 and 6).

A common feature of such follicles was the detachment of the oocyte with a few adhering cells of the corona radiata from the cumulus mass to become

TABLE 1

Mean capillary area $\left(\mathrm{mm}^{2}+\right.$ S.E.) within the vasculature of the theca interna of atretic and non-atretic sheep $(n=35)$ and pig $(n=6)$ follicles

\begin{tabular}{lllll}
\hline \multicolumn{1}{c}{ Follicles } & \multicolumn{2}{c}{ Sheep } & \multicolumn{2}{c}{ Pig } \\
\hline Wall & Cumulus & Wall & Cumulus \\
\hline Non-atretic & $64 \pm 4$ & $58 \pm 3$ & $52 \pm 15$ & $73 \pm 16$ \\
Tertiary atresia & $40 \pm 3$ & $56 \pm 3$ & $12 \pm 1$ & $19 \pm 3$ \\
\hline
\end{tabular}


TABLE 2

Nuclear status of oocytes from atretic and non-atretic porcine oocytes

\begin{tabular}{llrrrr}
\hline & & GV & $\%$ & GVBD & $\%$ \\
\hline Grade 1 & Not cultured & 10 & 100 & 0 & 0 \\
Grade 1 & Cultured & 8 & 100 & 0 & 0 \\
Grade 2 & Not cultured & 13 & 100 & 0 & 0 \\
Grade 2 & Cultured & 25 & 47 & 28 & 53 \\
*Grade 3 & Not cultured & 51 & 98 & 1 & 2 \\
Grade 3 & Cultured & 3 & 14 & 18 & 86 \\
Grade 2 (extra follicular) & Cultured & 1 & 7 & 14 & 93 \\
\hline
\end{tabular}

* An additional 40 oocytes were examined in section; all contained an intact germinal vesicle.

free within the antrum. Even in such oocytes, where virtually all contact between the gamete and somatic cells had been lost, germinal vesicle breakdown did not occur (fig. 4).

When atretic follicles (Grade 3) were cultured for $48 \mathrm{~h}$, almost $90 \%$ of the oocytes underwent germinal vesicle breakdown (table 2). This was accompanied by expansion and mucification of the cumulus. In the case of non-atretic follicles (Grade 1), as was shown by Gérard et al. (1979) germinal vesicle breakdown (GVBD) did not take place. In the intermediate group (Grade 2), $52 \%$ of oocytes showed GVBD. In such follicles there was extensive necrosis of the granulosa together with expansion of the cumulus. In those follicles in which the oocyte nucleus remained intact, the follicle cells did not show any signs of degeneration. In common with many other species, oocytes removed and cultured outside the follicle (extrafollicular oocytes) underwent GVBD.

\section{PLATE}

FIG. 1. - Part of the wall of a non-atretic pig follicle. Prominent blood vessels (arrows) are present in the theca interna (T.). A dividing cell can be seen in the granulosa (G). $\times 1100$.

FIG. 2. - Part of the wall from an atretic pig follic/e. Blood vessels (arrow) are very much reduced and there is a marked "loosening " of the cells of the theca interna (T) (cf. fig. 1). Pyknotic nuclei $(P)$ are present in the granulosa $(G) . \times 1000$.

FIG. 3. - Part of the cumulus of an atretic pig follic/e. Most of the cumulus cells are degenerate. The oocyte nucleus (arrow) is dictyate and contains an intact nucleolus. $\times 300$.

FIG. 4. - An oocyte lying free in the antrum of an atretic pig follic/e. Contact with cumulus cells has largely been lost and the nucleus is vesicular. $\times 900$.

FIG. 5. - Section of the edge of an oocyte from a non-atretic pig follicle. It contains lipid droplets (L), mitochondria (M) with few cristae, and smooth endoplasmic reticulum (S). $\times 3700$.

FIG. 6. - Section of an oocyte from an atretic (Grade 2) pig follic/e. The cytoplasm is similar to that of oocytes from non-atretic follicles (cf. fig. 5). $\times 4600$. 


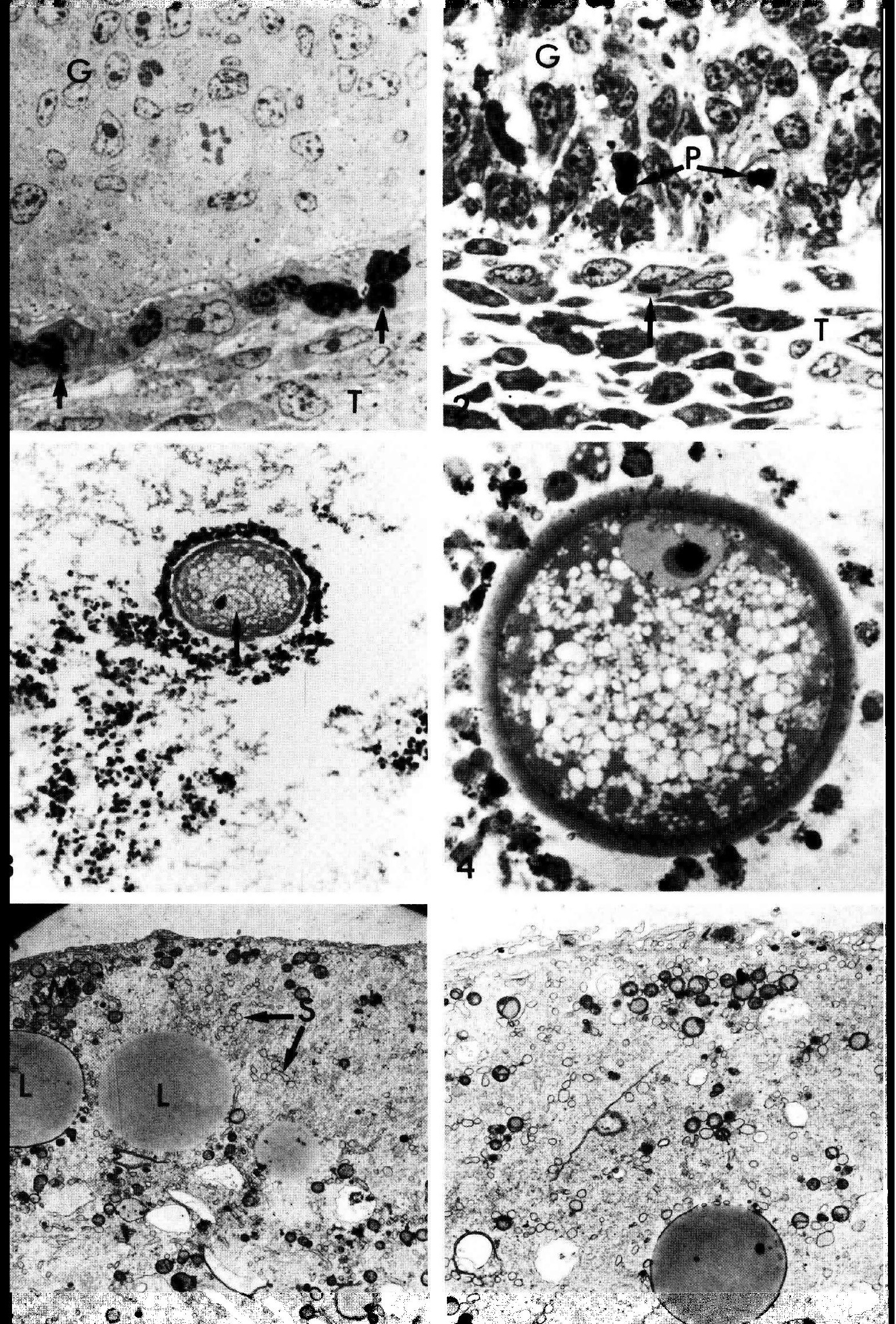




\section{Discussion.}

During follicular atresia, reduction in the thecal capillary bed underlying the granulosa takes place in the pig as well as in the sheep (Hay, Cran and Moor, 1976 ; present study). In the sheep, while pronounced degeneration of the granulosa is a characteristic feature, that of the theca interna is not as marked (O'Shea, Hay and Cran, 1978). In the pig, however, a gross change in the integrity of the theca is evident and the loss of luminal patency greater. This difference may be indicative of a greater sensitivity of porcine follicles to atretic conditions.

In the sheep, the maintenance of vasculature within the theca underlying the cumulus together with the continued integrity of these two areas contrasts with the degeneration present in the remainder of the follicle wall. This observation gives credence to the suggestion that a reduction in blood supply together with the elimination of metabolic by-products and a limitation of substrates possibly including gonadotrophins are likely to be involved in atresia. Conversely, the presence of an adequate vasculature is clearly necessary for follicular development.

The maintenance in the theca of patent capillaries beneath the cumulus of atretic sheep follicles indicates that some local protective factor is operative. By contrast, in the pig, loss of vasculature occurs to a similar extent both under the cumulus and membrana granulosa and is correlated with extensive cell death at these two sites. It seems unlikely, as in the sheep, that a protective control mechanism is present in this species.

In many species, the oocytes of large atretic follicles undergo pseudomaturation changes similar to those of the normal maturing oocyte (Byskov, 1978) and as in normal oocyte maturation, cumulus cell processes gradually disappear during atresia (Belterman, 1965 ; Thibault, Gérard and Ménézo, 1976). It has been suggested that meiotic inhibitors act on the oocyte after passage through transzonal processes (Tsafriri and Channing, 1975 ; Dekel and Beers, 1978 ; Hillensjö et al., 1979). Reduction in the passage of inhibitor to the oocyte resulting from the disruption of cumulus cell processes has been forwarded as a mechanism initiating oocyte maturation (Dekel and Beers, 1978, 1980 ; Dekel et al., 1981).

The finding that intercellular coupling is maintained in atretic sheep follicles and the oocytes remain in the germinal vesicle stage (Hay, Cran and Moor, 1976), appears to support the hypothesis that the uncoupling of cumulus cells from the oocyte initiates meiotic maturation. More recently, however, it has been shown that the resumption of meiosis in both the sheep (Moor et al., 1981) and the mouse (Eppig, 1982) is not initiated by a reduction in cumulus cell-oocyte coupling but that GVBD may precede the decline in intercellular coupling. In addition Peluso (1979) and Gondos (1982) have demonstrated that somatic cell degeneration precedes that of the oocyte in the rat.

In the pig, also, cumulus degeneration takes place without nuclear maturation. This further argues against the hypothesis that the resumption of meiosis 
in mammalian oocytes is initiated by the disruption of coupling between cumulus cells and the oocyte.

Reçu en juillet 1982.

Accepté en novembre 1982.

Acknowledgments. - One of us (J. C. O.) is indebted to the Medical Research Council for financial support.

Résumé. Vascularisation de la thèque et maturation de l'ovocyte au cours de l'atrésie folliculaire chez la brebis et la truie.

Pendant I'atrésie folliculaire chez la brebis et chez la truie, il y a une réduction prononcée de la vascularisation de la thèque interne sous la granulosa. Chez la brebis il n'y a pas de réduction des vaisseaux sanguins de la thèque interne près du cumulus qui reste viable. Au contraire, chez la truie, le cumulus dégénère pendant l'atrésie et la vascularisation sous-jacente est très réduite. Cependant, en dépit de la perte de contact entre les cellules folliculaires et l'ovocyte, la vésicule germinative reste intacte.

\section{References}

BELTERMAN R., 1965. Elektronen-Mikroskopische Befunde bei beginnender Follikelatresie im Ovar der Maus. Arch. Gynäkol., 200, 601-609.

BYSKOV A. G., 1978. Follicular atresia, 533-562. In JONES R. E., The vertebrate ovary, Plenum Press, New York.

DEKEL N., BEERS W. H., 1978. Rat oocyte maturation in vitro : relief of cyclic AMP inhibition by gonadotrophins. Proc. nat. Acad. Sci. U.S.A., 75, 4369-4373.

DEKEL N., BEERS W. H., 1980. Rat oocyte maturation in vitro : inhibition and induction of maturation in the presence or absence of the cumulus oophorus. Develop. Biol., 75, 247-254.

DEKEL N., LAWRENCE T. S., GILULA N. B., BEERS W. H., 1981. Modulation of cell-to-cell communication in the cumulus-oocyte complex and the regulation of oocyte maturation by LH. Devel. Biol., 85, 356-362.

EPPIG J. J., 1982. The relationship between cumulus cell-oocyte coupling oocyte meiotic maturation and cumulus expansion. Devel. Biol., 89, 268-272.

GÉRARD M., MÉNÉZO Y., ROMBAUTS P., SZÖLLÖSI D., THIBAULT C., 1979. In vitro studies of oocyte maturation and follicular metabolism in the pig. Ann. Biol, anim. Bioch. Biophys., $19,1521-1535$.

GONDOS B., 1982. Ultrastructure of follicular atresia in the rat. Gamete Res., 5, 199-206.

GREENWALD G. S., 1974. Role of follicle stimulating hormone in follicular development and ovulation, 293-325. In GREIGER S. R., Handbook of physiology, Sect. 7 Endocrinology, Vol. IV, part 2, Amer. Physiol. Soc., Washington.

HAY M. F., CRAN D. G., 1978. Differential response of components of sheep Graafian follicles to atresia. Ann. Biol. anim. Bioch. Biophys., 18, 453-460.

HAY M. F., CRAN D. G., MOOR R. M., 1976. Structural changes occurring during atresia in sheep ovarian follicles. Cell Tiss. Res., 169, 515-529.

HILLENSJÖ T., KRIPNER A. S., POMERANTZ S. H., CHANNING C. P., 1979. Action of porcine follicular fluid oocyte maturation inhibitor in vitro: possible role of the cumulus cells, 283291. In CHANNING C. P., MARSH I. M., SADLER W. A., Ovarian follicular and corpus luteum function, Plenum Press, New York.

MOOR R. M., TROUNSON A. O., 1977. Hormonal and follicular factors affecting maturation of sheep oocytes in vitro and their subsequent developmental capacity. J. Reprod. Fert., 49, 101-109. 
MOOR R. M., HAY M. F., DOTT H. M., CRAN D. G., 1978. Macroscopic identification and steroidogenic function of atretic follicles in sheep. J. Endocr., 77, 309-318.

MOOR R. M., OSBORN J. C., CRAN D. G., WALTERS D. E., 1981. Selective effect of gonadotrophins on cell coupling, nuclear maturation and protein synthesis in mammalian oocytes. J. Embryol. exp. Morphol., 61, 347-365.

O'SHEA J. D., CRAN D. G., HAY M. F., MOOR R. M., 1978. Ultrastructure of the theca interna of ovarian follicles in sheep. Cell Tiss. Res., 187, 457-472.

O'SHEA J. D., HAY M. F., CRAN D. G., 1978. Ultrastructural changes in the theca interna during follicular atresia in sheep. $J$. Reprod. Fert., 54, 183-187.

PELUSO J. J., 1979. In vitro maturation of oocytes collected from atretic follicles, 85-88. In MIDGLEY A. R., SADLER W. A., Ovarian follicular development and function, Raven Press, New York.

RAJAKOSKI E., 1960. The ovarian follicular system in sexually mature heifers with special reference to seasonal cyclic and left-right variations. Acta endocr. Copnh., 34, 1-68.

THIBAULT C., GÉRARD M., MÉNÉZO Y., 1976. Nuclear and cytoplasmic aspects of mammalian oocyte maturation in vitro in relation to follicle size and fertilization. Progr. Reprod. Biol., 1, 233-240.

TSAFRIRI A., CHANNING C. P., 1975. Inhibitory influence of granulosa cells and follicular fluid upon porcine oocyte meiosis in vitro. Endocrinology, 91, 922-927.

WEIR B. J., ROWLANDS I. W., 1977. Ovulation and atresia, 265-301. In ZUCKERMAN S., WEIR B. J., The ovary, 2nd Edn., Vol. 1, Acad. Press, London. 